\title{
Applying a social-ecological well-being approach to enhance opportunities for marine protected area governance
}

\author{
Irene Brueckner-Irwin, Derek Armitage ${ }^{1,2}$ and $\underline{\text { Simon Courtenay }}^{2,3,4}$
}

\begin{abstract}
The design and implementation of ecologically effective marine protected areas (MPAs) are influenced by social acceptance and the impact of MPAs on communities. Integrative analyses of the social and ecological determinants of marine conservation efforts and MPA networks are lacking but are needed to achieve desired outcomes. We developed and applied a "socialecological well-being" (SEWB) approach to critically examine the linkages between MPAs and well-being in Southwest New Brunswick (Bay of Fundy, Canada). SEWB is defined as a social-ecological system state in which ecological resilience is sustained, while human needs are met and the quality of life of individuals is maintained. We examined (1) how stakeholders perceive benefits and costs of MPAs in relation to SEWB, and (2) how well-being insights contribute to the effectiveness of MPA governance. Using a qualitative case study approach, we conducted 49 semistructured interviews and 4 focus groups with fishers and other key informants at an existing MPA, as well as at an ecologically and biologically significant area that is a candidate for a future MPA. We identified 15 attributes of SEWB that related to MPAs, such as fishery access, community relations, place identity, and natural capital. Three key governance insights for decision makers emerged from the identification of these attributes: (1) displacement attributable to MPAs has implications across material, relational, subjective, and ecological dimensions; (2) effective collaboration is critical for community support, but perspectives about what constitutes effective collaboration may vary across stakeholder groups; and (3) aspects of MPA design fit poorly with the local context because they do not take social and ecological dynamics into account. Our findings empirically demonstrate the applicability of the SEWB framework, suggest a need to focus more on governance processes and improving fit, and highlight barriers to aligning national and local conservation priorities.
\end{abstract}

Key Words: Bay of Fundy; biodiversity; conservation; fisheries; governance; marine protected areas; perceptions; resilience; well-being

\section{INTRODUCTION}

We apply an integrative social-ecological well-being (SEWB) perspective to critically examine the linkages between marine protected areas (MPAs) and well-being in an inshore fishing community in the Bay of Fundy, Canada. Our objective is to understand (1) how stakeholders perceive benefits and costs of MPAs in relation to SEWB, and (2) how SEWB insights contribute to the effectiveness of MPA governance.

The Canadian government is currently prioritizing marine conservation by expanding its network of MPAs (Office of the Prime Minister of Canada 2015, 2018) and reviewing relevant oceans and fisheries legislation to incorporate stronger environmental protections (e.g., Parliament of Canada 2017, 2018, Bujold and Simon 2018, Standing Committee on Fisheries and Oceans [FOPO] 2018). However, these activities are occurring alongside decreasing trends in fishery access for coastal communities (Barnett 2018, Bennett et al. 2018) and heightened awareness of the social impacts of conservation initiatives. This research is a timely contribution to the Canadian marine conservation policy context and also to broader debates about the challenges of aligning international and national conservation priorities with local social and ecological realities. Although MPAs are a core conservation strategy, their effectiveness is less certain (Giakoumi et al. 2018, Watson and Hewson 2018).

Protection of global ocean area increased fivefold from 2006 to 2013, and many nations are currently striving to attain Aichi Target 11 under the Convention on Biological Diversity (CBD) to protect $10 \%$ of coastal and marine areas by 2020 (Boonzaier and Pauly 2016). The primary objectives of MPAs are to conserve biodiversity and manage fisheries more sustainably (Pita et al. 2011, Woodcock et al. 2017) by delimiting regions of ocean space where special rules and management considerations limit human use. However, the expansion of MPAs and "other effective areabased conservation measures" raises concerns about their associated social implications (e.g., Charles and Wilson 2009, Agardy et al. 2011, Rees et al. 2013b, Voyer et al. 2014, Ferraro and Pressey 2015, Chan 2017).

Enhanced understanding of the social implications of MPAs is necessary because ecological outcomes depend in part on social factors (Mascia et al. 2017). Community support and perceived benefits encourage compliance (Agardy et al. 2011, Bennett 2016), whereas stakeholder resistance can hinder MPA implementation (Lubchenco and Grorud-Colvert 2015) and result in "residual reserves" (Devillers et al. 2015). Aichi Target 11 also stipulates that protected areas should be "effectively and equitably managed" (CBD 2010), and decision makers have an ethical responsibility to ensure that conservation interventions result in minimum harm to affected communities (Woodhouse et al. 2015).

The social consequences of MPAs for coastal communities are increasingly documented (see Sowman and Sunde 2018). Benefits and costs of MPAs to people and coastal communities have been observed, such as enhanced fishery resources (e.g., Angulo-Valdés and Hatcher 2010) and displacement from traditional fishing grounds (e.g., Rees et al. 2013a), and can impact different people in different ways (e.g., Cinner et al. 2014). However, much existing

${ }^{1}$ Environmental Change and Governance Group, University of Waterloo, ${ }^{2}$ School of Environment, Resources and Sustainability, University of Waterloo, ${ }^{3}$ Canadian Water Network, ${ }^{4}$ Canadian Rivers Institute 
Table 1. Description of the four dimensions of social-ecological well-being (SEWB) and sample attributes. WeD, Wellbeing in Developing Countries.

\begin{tabular}{|c|c|c|c|}
\hline Theoretical Origin & $\begin{array}{l}\text { Dimension of } \\
\text { SEWB }\end{array}$ & Description & Sample Attributes \\
\hline \multirow{3}{*}{$\begin{array}{l}\text { WeD three- } \\
\text { dimensional social } \\
\text { well-being }\end{array}$} & Material & $\begin{array}{l}\text { The objective physical requirements of life, i.e., what } \\
\text { people have } e^{1,2}\end{array}$ & $\begin{array}{l}\text { Income, assets, shelter, food, access to } \\
\text { resources }^{2}\end{array}$ \\
\hline & Relational & $\begin{array}{l}\text { How social relationships affect well-being, i.e., what people } \\
\text { can do with what they have } e^{1,2}\end{array}$ & $\begin{array}{l}\text { Relationships of affection, relations with the } \\
\text { state, social institutions, rules and norms that } \\
\text { dictate access to resources }\end{array}$ \\
\hline & Subjective & $\begin{array}{l}\text { How people think and feel about their situation in life, i.e., } \\
\text { people's own perceptions }{ }^{1}\end{array}$ & $\begin{array}{l}\text { Values, beliefs, satisfaction, self-identity, } \\
\text { spirituality }{ }^{2,3}\end{array}$ \\
\hline Resilience thinking ${ }^{4}$ & Ecological & The capacity of an ecosystem to absorb disturbances ${ }^{5}$ & $\begin{array}{l}\text { Biological diversity, modularity, openness, } \\
\text { reserves, capital }\end{array}$ \\
\hline
\end{tabular}

research focuses on narrow sets of predetermined indicators with limited input from communities (e.g., Gjertsen 2005, Mascia et al. 2010, Stevenson et al. 2013, Ngoc 2018). Without greater input from coastal communities, assessments risk missing the full range of implications of MPAs for key stakeholders, and our understanding of how social dynamics affect and are affected by MPAs will be constrained.

The social and ecological outcomes of MPAs also depend on governance arrangements (Bennett and Dearden 2014, Giakoumi et al. 2018). Governance refers to how communities, societies, and organizations may organize themselves to make decisions about important issues of concern, e.g., use or conservation of fishery resources (Armitage et al. 2017). Engaging stakeholders in decision making can enhance MPA effectiveness, i.e., the ability of an MPA to meet its stated objectives (Pomeroy et al. 2004), by increasing social acceptance and support for MPAs (Chaigneau and Daw 2015) and enabling the incorporation of social and ecological contextual factors that are critical for MPA success (Bennett and Dearden 2014, Hogg et al. 2017). Stakeholder participation can also enhance the "fit" of governance, by aligning governance with underlying social and ecological systems, e.g., priorities of local communities and functional aspects of ecosystems (Epstein et al. 2015, Berdej and Armitage 2016).

\section{A FRAMEWORK FOR SOCIAL-ECOLOGICAL WELL- BEING}

We build on existing frameworks that assess the effectiveness of MPAs and marine policy (e.g., Rees et al. 2013a, Rossiter and Levine 2014, Biedenweg et al. 2016, Mahajan and Daw 2016) to develop an integrative framework for SEWB (Fig. 1). We apply this framework to assess community perceptions of MPA development in the Bay of Fundy, Canada, and with an effort to consider place-based social and ecological dimensions. This framework operationalizes emerging thinking about the interplay between social well-being and ecological concepts (Armitage et al. 2012, Loring et al. 2016, Karst 2017) by integrating ecological resilience (Walker et al. 2004) and the Wellbeing in Developing Countries (WeD) conceptualization of three-dimensional social well-being (McGregor 2007). We define SEWB as a system state in which (1) the ecological subsystem can absorb disturbances and reorganize to retain essentially the same function, structure, identity, and feedbacks; (2) the social subsystem exists such that human needs are met, one can act meaningfully to pursue one's goals, and one enjoys a satisfactory quality of life; and (3) the subsystems interact with each other (adapted from Walker et al. [2004] and McGregor [2008]). The framework consists of four interacting dimensions - material, relational, subjective, and ecological - and their associated attributes (Table 1) but does not prescribe the extent or direction of interactions between them. The framework presumes that SEWB may influence and be influenced by both MPA governance and MPA effectiveness.

Fig. 1. Framework for social-ecological well-being.

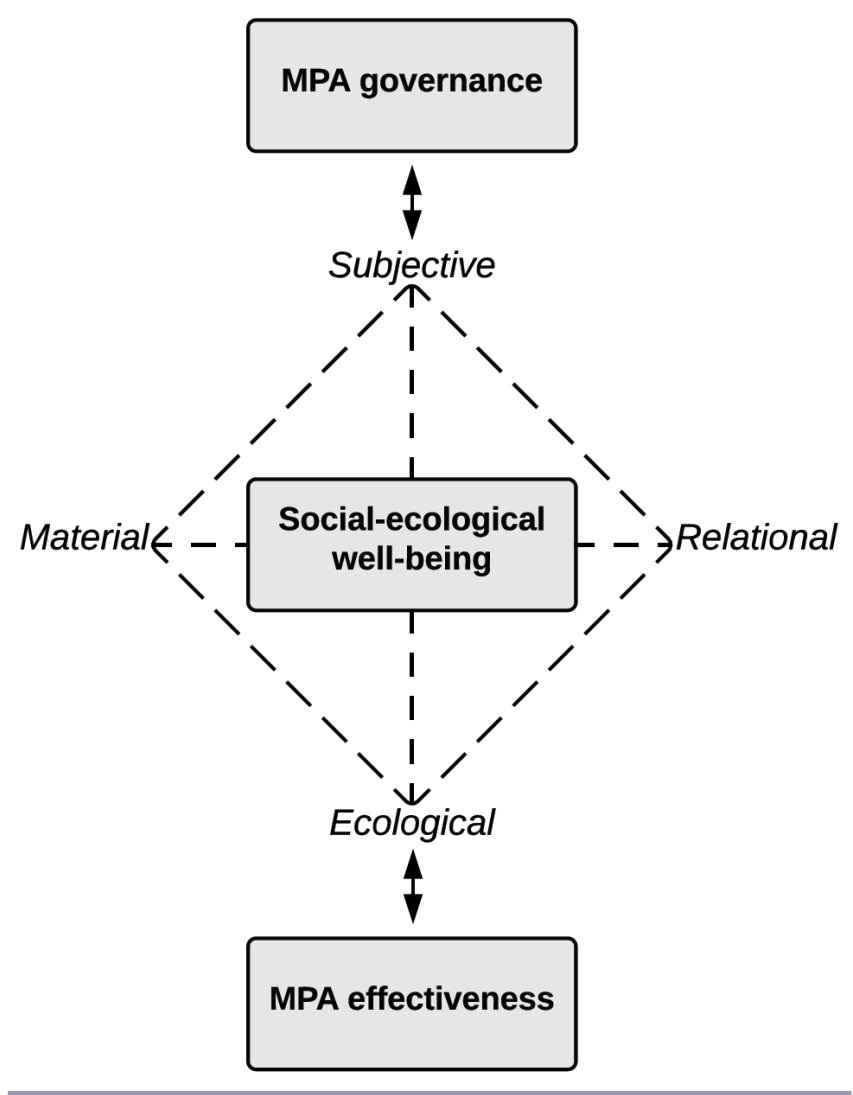


The concept of well-being is useful because it is inherently important and may improve perceived legitimacy and policy relevance of conservation efforts (Milner-Gulland et al. 2014, Woodhouse et al. 2015). The WeD framework has been described as the most comprehensive and holistic in comparison to a multitude of other well-being approaches and is particularly well suited to capture local context and diverse values in highly social inshore fisheries (Coulthard et al. 2011, Weeratunge et al. 2014). However, enhancing social well-being may be insufficient to achieve sustainability if it comes at the cost of ecological degradation, so it is useful to explicitly consider ecological outcomes as well (Armitage et al. 2012). There is debate around if and when human well-being and ecosystem health are interdependent (see Raudsepp-Hearne et al. 2010), and research has demonstrated that conservation outcomes can be mutually beneficial (see Loring et al. 2016) or involve trade-offs (e.g., Halpern et al. 2013, Daw et al. 2015) between social and ecological variables. Our framework links attributes of social well-being with ecological resilience to help identify and consider those potential trade-offs.

We apply ecological resilience thinking because it recognizes attributes (e.g., feedbacks across scales, complexity, and uncertainty) that are inherent in dynamic ecological systems (Walker et al. 2004, Folke 2006, Kofinas 2009, Allen et al. 2014) and consequently must be addressed to achieve sustainability for future generations (Xu et al. 2015). Enhancing resilience is often an objective of MPAs (Bennett and Dearden 2014, Rees et al. 2014, Weigel et al. 2014), and attributes of ecological resilience such as connectivity and biodiversity guide principles of MPA design (e.g., CBD 2010, Lausche 2011). Protected areas may also be viewed as "reserves" of natural capital that act as sources of renewal and reorganization after disturbance. However, resilience applications tend to overlook for whom maintaining the resilience of an existing state is desirable and assume that the underlying dynamics of ecological and social systems are the same (Cote and Nightingale 2012, Brown 2014, Cretney 2014). Rather than focusing on social resilience, our framework applies a social conception of well-being in which a broader suite of normative values and human agency are reflected (Brown 2014).

The SEWB framework we use builds on previous developments in the field and current research on the impacts of MPAs (e.g., Britton and Coulthard 2013, Weeratunge et al. 2014, Mahajan and Daw 2016). However, in bringing together social well-being and ecological resilience, our framework provides novel analytical contributions relevant to our case. First, the framework enables examination of the holistic impacts of MPAs and ties together the theoretical strengths of social well-being and ecological resilience. Second, the framework is useful for contextualizing how MPAs impact different people in different ways (material, relational, and subjective), as well as the various ways in which people are connected to ecological systems. Third, the approach allows for trade-offs across variables. Resilience and social wellbeing are both normative concepts, and trade-offs can have different meanings for people based on their values and interests (Halpern et al. 2013). Explicitly addressing trade-offs reduces the likelihood of resistance from "losing" stakeholders, conflict, and unintended perverse consequences (Daw et al. 2015) and can contribute to transparent decision making around "hard choices" (McShane et al. 2011). Fourth, the framework aims to recognize ecosystem dynamics by grappling with ecological resilience rather than only ecological outcomes.

The SEWB framework we have presented offers a novel pathway for integrative thinking about MPAs in our case study context. However, the framework is not a panacea. For example, the capacity of the framework to disaggregate the impacts of MPAs depends in part on methodological application, and assessing resilience is challenging given the complexity and dynamic nature of ecosystems (Folke 2016). In the following sections, we describe our use of the SEWB approach to guide data collection and frame our results and, in doing so, reflect on its strengths and limitations.

\section{METHODS}

\section{Case study context}

The Bay of Fundy coastal region of Southwest New Brunswick (Fig. 2) provides the context for this analysis. The Bay of Fundy is part of the larger Gulf of Maine system and is characterized by high biodiversity, a wide range of unique habitats, and extremely high tides (Thompson 2010). Southwest New Brunswick is a mostly rural area with approximately 65,300 inhabitants (Statistics Canada 2017). The communities are culturally attached to the inshore fishery and depend economically on fish harvesting and related processing (Lapointe 2013), dock work, marketing, and transportation (Knott and Neis 2017). Inshore fishers operate relatively small boats (Wiber et al. 2012) and generally fish within informal areas that are smaller than their legally designated fishing areas (Walters 2007). In recent years, declines in important fish stocks such as herring (Clupea harengus) and groundfish (Wiber et al. 2012), warming waters (Lapointe 2013), and the propagation of salmon (Salmo salar) aquaculture (Walters 2007) have caused concern in the inshore fishing community. Other marine activities include shipping and tourism, e.g., whale watching.

Fig. 2. Map of case study region in Southwest New Brunswick.

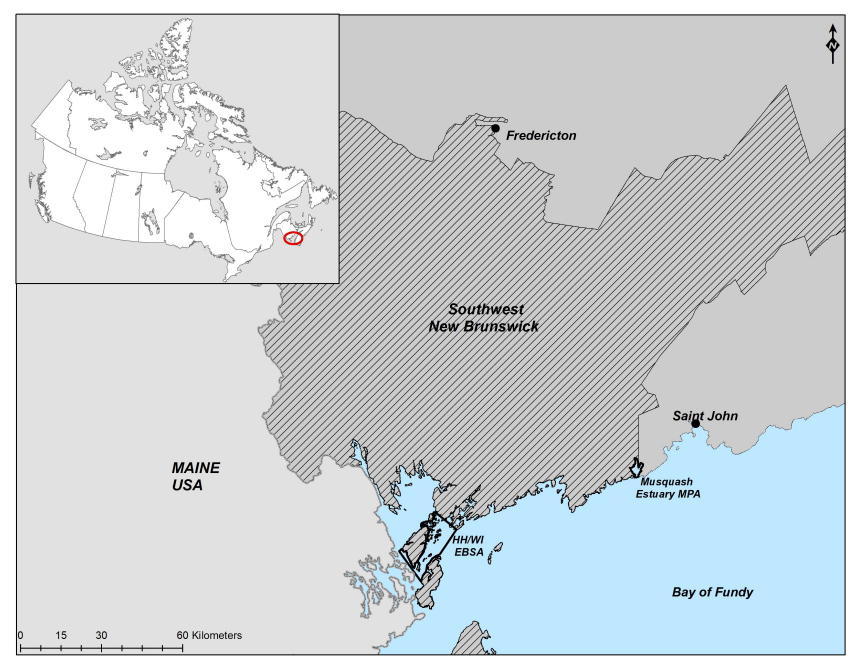

The federal department of Fisheries and Oceans Canada (DFO) is responsible for implementing and managing a national network of MPAs, including coverage in the Bay of Fundy. This includes the Musquash Estuary MPA, and several ecologically and 
Table 2. Description of case study locations. EBSA, ecologically and biologically significant area; HH/WI, Head Harbour, West Isles Archipelago, and The Passages; MPA, marine protected area.

\begin{tabular}{|c|c|c|c|c|}
\hline & Designation Status & Area Description & Conservation Focus & Level of Fishing Activity \\
\hline Musquash Estuary & MPA & Salt marsh and tidal estuary ${ }^{1}$ & $\begin{array}{l}\text { Largest remaining intact salt marsh in the Bay } \\
\text { of Fundy }{ }^{1}\end{array}$ & Low $^{2}$ \\
\hline $\mathrm{HH} / \mathrm{WI}$ & EBSA & $\begin{array}{l}\text { Open ocean and archipelago } \\
\text { of islands }\end{array}$ & $\begin{array}{l}\text { Ecologically unique, high productivity, and } \\
\text { high benthic and marine mammal biodiversity } \\
\end{array}$ & $\operatorname{High}^{2}$ \\
\hline
\end{tabular}

biologically significant areas (EBSAs) that have been identified for consideration in the MPA network (DFO 2018). Our case study focuses on two of these designations (Table 2). The first is the Musquash Estuary MPA, currently the only existing MPA under Canada's Oceans Act in the Bay of Fundy. With few exceptions, the MPA's regulations are lenient (Dehens and Fanning 2018) and allow most fishing activities to continue within specified zones (DFO 2008). Our aim at Musquash was to examine the implications of the MPA on SEWB since its designation in 2006. The second case is the EBSA known as "Head Harbour, West Isles Archipelago, and The Passages" (HH/WI). Our aim at HH/WI was forward looking, to understand how a prospective MPA would affect stakeholders.

\section{Data collection}

Using a qualitative case study approach (Yin 2014), we conducted semistructured interviews $(n=49)$ and four focus groups for our primary data collection methods (Table 3 ). On-site observations were recorded throughout all stages of data collection and through participant observation, e.g., fishing and ecotourism. Literature from academic and other sources was also reviewed for information relevant to the field site. Field components in Southwest New Brunswick were conducted between June and November 2016, with a verification trip in October 2017 during which we disseminated results through presentations and meetings with decision makers and other stakeholders. Participants included inshore fishers who had fished within or adjacent to either designation and other key informants who had held official positions giving them authority, expertise, or access to information about MPAs in the case study region, i.e., representatives from marine industries, government, advisory committees, environmental nongovernmental organizations, and First Nations. Snowball sampling (Koerber and McMichael 2008) was used to recruit interview participants, and all fishers interviewed were invited to participate in focus groups.

Our overall approach was inductive, as well-being is context dependent (White 2009), and it is "unlikely that local people will cognitively parcel their well-being into the same categories that typify various academic frameworks" (Loring et al. 2016:155). We investigated perceptions because they are invaluable for understanding conservation outcomes (Bennett 2016) and the social acceptance of MPAs (Leleu et al. 2012). Perceptions can reveal which aspects of well-being and resilience are prioritized by people, and fishers may be able to provide the most current observations of ecological resilience given how much time they spend on the water. During data collection, we included opportunities for participants to raise other relevant topics to reduce the risk of overlooking important related issues. Interview questions were adapted from WeD methodology (e.g., Britton and Coulthard 2013, Coulthard et al. 2015). Specifically, SEWB was explored using the following prompts: access to materials and natural resources (i.e., material well-being); relationships with individuals and institutions that influence quality of life (i.e., relational well-being); subjective requirements to have a good quality of life (i.e., subjective well-being); and threats to environmental quality in the Bay of Fundy, as well as things that help the environment cope with or buffer these threats (i.e., ecological resilience). We asked participants to self-identify attributes for each dimension of SEWB, and subsequently describe if and how these attributes interact with MPA processes.

Table 3. Summary of primary data collection methods. MPA, marine protected area; SEWB, social-ecological well-being.

\begin{tabular}{|c|c|c|}
\hline & Interviews & Focus Groups \\
\hline Sample size & $\begin{array}{l}27 \text { Fishers } \\
22 \text { Key informants }\end{array}$ & 13 Fishers (4 groups) \\
\hline $\begin{array}{l}\text { Sampling } \\
\text { technique }^{\dagger}\end{array}$ & Snowball & $\begin{array}{l}\text { Purposeful: all fishers } \\
\text { interviewed were invited to } \\
\text { participate }\end{array}$ \\
\hline Location & $\begin{array}{l}\text { In-person at various } \\
\text { locations (participants' } \\
\text { homes, offices, wharves, } \\
\text { etc.), e-mail }(\mathrm{n}=1) \text {, and } \\
\text { phone }(\mathrm{n}=1)\end{array}$ & $\begin{array}{l}\text { In-person at community } \\
\text { centers }\end{array}$ \\
\hline $\begin{array}{l}\text { Data } \\
\text { collected }\end{array}$ & $\begin{array}{l}\text { Description of fishing } \\
\text { activities, self-identified } \\
\text { attributes of SEWB, and } \\
\text { subsequent links to benefits } \\
\text { and costs of MPAs }\end{array}$ & $\begin{array}{l}\text { Broader SEWB priorities of } \\
\text { fishers }\end{array}$ \\
\hline
\end{tabular}

Focus groups were loosely based on sustainability visioning (see Wiek and Iwaniec 2014), where participants were asked to discuss desirable visions of the future in terms of SEWB priorities. The purpose was to compare fishers' priorities for SEWB to perceptions about MPAs and generate insights to contribute to the effectiveness of MPA governance. We grouped participants homogeneously by location and age, based on local advice to maximize participation. We asked fishers to (1) identify valuebased statements about the future that would be critical to attain the best possible state of well-being in the future, e.g., "more fish stocks"; (2) categorize each statement into one of the four dimensions of SEWB; and (3) rank the importance of each statement. Fishers ranked statements with ambivalence, so the only focus group data we used for analysis were the qualitative discussions. We audio-recorded all focus groups and most interviews $(n=45)$ when we received consent to do so and transcribed recordings in full. 
Table 4. Perceptions of benefits and costs of marine protected areas (MPAs) across social-ecological well-being attributes and cases: benefit (+), cost (-), mixed ( \pm ), uncertain (?), not identified (n/a). HH/WI, Head Harbour, West Isles Archipelago, and The Passages.

\begin{tabular}{|c|c|c|c|c|c|}
\hline \multirow[t]{2}{*}{ Dimension } & \multirow[t]{2}{*}{ Attribute } & \multicolumn{4}{|c|}{ Fishing Community Perspectives } \\
\hline & & \multicolumn{2}{|r|}{ Musquash } & \multicolumn{2}{|r|}{$\mathrm{HH} / \mathrm{WI}$} \\
\hline \multirow[t]{4}{*}{ Material } & Fishery resources & $?$ & $\begin{array}{l}\text { Uncertain as to influence on } \\
\text { commercial fish stocks }\end{array}$ & $?$ & $\begin{array}{l}\text { Uncertain potential to enhance commercial fish } \\
\text { stocks }\end{array}$ \\
\hline & Fishery access & + & $\begin{array}{l}\text { Fishery access maintained and } \\
\text { likelihood of gear conflict reduced }\end{array}$ & - & $\begin{array}{l}\text { Anticipated access loss and associated } \\
\text { implications for other well-being attributes }\end{array}$ \\
\hline & Income & & $\mathrm{n} / \mathrm{a}$ & - & $\begin{array}{l}\text { Anticipated loss of income attributable to access } \\
\text { loss, and consequences for fishery-dependent } \\
\text { local economy }\end{array}$ \\
\hline & Additional resources & + & $\begin{array}{l}\text { MPA-related research and monitoring } \\
\text { dedicated to estuary region }\end{array}$ & + & $\begin{array}{l}\text { Potential to draw in additional funding and } \\
\text { monitoring resources }\end{array}$ \\
\hline \multirow[t]{5}{*}{ Relational } & $\begin{array}{l}\text { Collaborative decision } \\
\text { making }\end{array}$ & + & $\begin{array}{l}\text { Opportunities for community } \\
\text { participation in decision making from } \\
\text { the outset }\end{array}$ & - & $\begin{array}{l}\text { Doubts about transparency, trust, and future } \\
\text { opportunities for participation }\end{array}$ \\
\hline & Community relations & + & $\begin{array}{l}\text { Enhanced land-based community } \\
\text { relations attributable to adjacent land } \\
\text { donations and cooperation }\end{array}$ & 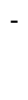 & $\begin{array}{l}\text { Anticipated conflict attributable to displacement } \\
\text { and consequent encroachment, and potential for } \\
\text { MPAs to become a polarizing community issue }\end{array}$ \\
\hline & Enforcement & & $\mathrm{n} / \mathrm{a}$ & $?$ & $\begin{array}{l}\text { Questions about how an MPA would be enforced } \\
\text { given existing enforcement challenges }\end{array}$ \\
\hline & Learning & & $\mathrm{n} / \mathrm{a}$ & - & $\begin{array}{l}\text { Devalued existing knowledge and anticipated } \\
\text { relearning required }\end{array}$ \\
\hline & Markets & + & $\begin{array}{l}\text { Potential for third-party sustainability } \\
\text { certifications }\end{array}$ & \pm & $\begin{array}{l}\text { Potential for third-party sustainability } \\
\text { certifications, but may come with strings attached }\end{array}$ \\
\hline \multirow[t]{3}{*}{ Subjective } & Place-identity & + & $\begin{array}{l}\text { Increased sense of pride for land- } \\
\text { based community }\end{array}$ & - & Loss of cultural and familial heritage if displaced \\
\hline & Equity & + & $\begin{array}{l}\text { Win-win MPA among community } \\
\text { stakeholders }\end{array}$ & 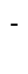 & $\begin{array}{l}\text { Inshore fishers expected to bear highest burden } \\
\text { of costs }\end{array}$ \\
\hline & Adaptability & - & $\begin{array}{l}\text { Ability to access emerging fisheries has } \\
\text { been restricted }\end{array}$ & - & $\begin{array}{l}\text { Future fishing options will be restricted with } \\
\text { permanent regulations }\end{array}$ \\
\hline \multirow[t]{3}{*}{ Ecological } & Natural capital & + & $\begin{array}{l}\text { Protects naturalness and intactness of } \\
\text { ecosystem }\end{array}$ & + & $\begin{array}{l}\text { Ability to protect naturalness, biodiversity, and } \\
\text { productivity }\end{array}$ \\
\hline & Disturbances & + & Keeps out heavy industry & \pm & $\begin{array}{l}\text { Potential to restrict heavy industry, but also for } \\
\text { adjacent overfishing attributable to reallocation } \\
\text { of fishing effort }\end{array}$ \\
\hline & Scale & + & $\begin{array}{l}\text { Adjacent land conservation prompted } \\
\text { by MPA is beneficial for protection }\end{array}$ & - & $\begin{array}{l}\text { Static MPA reduces ability to react to changing } \\
\text { environment }\end{array}$ \\
\hline
\end{tabular}

Data analysis was framed around the four dimensions of SEWB and governance themes to address our research objectives. To understand stakeholder perceptions of MPAs in relation to SEWB, we coded all transcripts using NVivo 11 software (QSR International) by identifying emergent well-being attributes that were perceived to interact with MPAs. Every one of these attributes was then categorized into the four dimensions of SEWB (Table 4). Other well-being attributes and priorities expressed by participants, i.e., those unrelated to MPAs, are not systematically presented. To generate SEWB insights and their implications for governance, we focused on the subset of well-being attributes that participants perceived negatively, with the aim of minimizing the costs associated with MPAs. Within this subset, we grouped attributes into governance-related categories, i.e., crosscutting themes. We did so to identify leverage points where governance could enhance SEWB as well as stakeholder support, because MPA effectiveness is dependent in part on how stakeholders experience their interactions with MPAs (Agardy et al. 2011, Bennett and Dearden 2014, Lubchenco and Grorud-Colvert 2015).

We conducted verification checks of our data analysis by providing summaries of transcripts to all participants for feedback, as well as presenting initial findings to 26 stakeholders for feedback on our verification trip. This research was conducted with approval by the University of Waterloo's Office of Research Ethics (Approval \#21516). All data collection followed informed consent processes.

\section{SOCIAL-ECOLOGICAL WELL-BEING INSIGHTS FOR MARINE PROTECTED AREA GOVERNANCE}

Perceptions of the benefits and costs of marine protected areas We address our first research objective by describing perceptions of the benefits and costs of MPAs in the inshore fishing community of Southwest New Brunswick. Participants identified a broad range of attributes across all four dimensions of SEWB that relate to MPAs (Table 4). Overall, perceptions at Musquash were generally neutral or positive, as opposed to generally negative perceptions at $\mathrm{HH} / \mathrm{WI}$.

\section{Material well-being}

Material well-being refers to what people have, or the objective physical requirements of life, including access to resources and income (McGregor 2007, Coulthard et al. 2015). In terms of resources, fishers indicated that their priorities were to protect or enhance fishery resources (e.g., commercial stocks) but were 
skeptical about whether coastal MPAs could do this. Participants also raised serious concerns about families and communities losing access to fishing grounds because of MPA restrictions, and associated consequences (e.g., income loss). Overwhelmingly, fishers indicated that a loss of access would offset any long-term benefits of MPAs. This is consistent with experiences elsewhere, where MPA benefits such as fish spillover have not been perceived to offset costs of displaced fishing effort from MPAs (Jones 2008, Stevenson et al. 2013, Cinner et al. 2014). Notably, in this research context, fishers agreed that a restrictive MPA at HH/WI based on its current boundaries would displace the majority of fishers in adjacent communities. Access loss has been reported in the Bay of Fundy as a result of other industries such as aquaculture (e.g., Wiber et al. 2012), and one informant expressed that MPAs would exacerbate these access issues:

[Fishers] are losing access constantly. They lost a lot of access with the aquaculture industry, with all of the energy development in Saint John Harbor, and the impact of all the tankers ... MPAs is another thing that will restrict their access. (Informant 11)

Musquash was seen as an exception, as it maintains most fishing access but acts as a "sanctuary" from heavier industrial activities, reducing the likelihood of gear conflict around the MPA with those industries. Indeed, resource extraction activities have been regulated inconsistently across existing MPAs in Canada (Canadian Parks and Wilderness Society [CPAWS] 2015).

\section{Relational well-being}

Relational well-being refers to what people can do with what they have and how their interactions with institutions, rules, and individuals influence the pursuit of well-being (McGregor 2007, Coulthard et al. 2015). Collaborative decision making, i.e., the ability to provide input into decisions about MPAs, was the most referenced attribute contributing to relational well-being. At Musquash, several participants noted that MPA planning and management processes had been community based and involved good levels of trust. In contrast, decision making for proposed expansion of the MPA network was not perceived as collaborative. This is largely because of the federal mandate to increase MPA coverage by 2020, a mandate for which the implications have not been fully discussed within coastal communities. Some recognized the importance of the mandate to mobilize important discussions and resources for ocean protection, whereas others worried it was driving top-down decision making to attain targets rather than meaningful conservation.

I'm not against marine protected areas, but I am against driving it down people's throats and putting people out of work. (Fisher 19)

Many fishers were also unclear about the purpose and design of MPAs and worried about the extent of collaboration in the future. Some attributed this to ineffective communication, but many fishers expressed mistrust of DFO and the government more broadly.

\section{There's no trust. Absolutely no trust. (Fisher 16)}

Some nonfisher informants recognized trust issues as well, but they tended to view the role and intentions of DFO more optimistically, pointing out that DFO has been consulting with different stakeholder groups on an ongoing basis in the region. These findings are similar to another case in which fishers' low trust in MPA management entities influenced their overall satisfaction with MPA network implementation, despite extensive stakeholder participation (Ordoñez-Gauger et al. 2018).

Participants discussed the impact of MPAs on community relations, including the relationships among fishers and within the broader community, e.g., local residents. Several participants expressed that the Musquash MPA had instilled a sense of community for nearby landowners, many of whom have donated lands for adjacent conservation. However, participants noted the potential for MPAs to become a polarizing issue within the community. This is an experience that has occurred in other jurisdictions (e.g., Weible 2008). Some participants also recalled previous experiences with divisive issues, such as an earlier marine conservation proposal in the region (see Walters and Butler 1995). Fishers also expressed that community relations could be influenced if an MPA caused displacement from fishing grounds, leading to a redistribution of effort, crowding, and spatial conflict.

If you push somebody out of an area they've been fishing all their life, they've got to go somewhere, and it causes more crowding in a smaller place. Everybody gets less 'cause you're competing for the same resource instead of having the fleet spread out, and you're getting gear tangled around your neighbor. It's no good. (Fisher 24)

Fishers explained that moving to new fishing grounds would require extensive relearning on fishing new areas. Learning how and where to fish is an iterative social process that occurs among fishers on and across fishing boats, influencing fishing effort and catch and therefore how resources are accessed. Fishers challenged a common notion that transition to alternative sites and/or gear choices is a relatively easy process. Such shifts risk devaluing their previous experiences and local knowledge, which had often occurred within families over generations. Indeed, the $\mathrm{HH} / \mathrm{WI}$ area is notorious for unique tidal currents, magnifying the challenge in learning how to fish.

\begin{abstract}
I've spent 16 years of my life so far learning how to fish in that spot. It's almost like I have a degree for fishing in here. The government thinks that people can just go out and set traps there and you catch lobsters. That isn't the case. My dad has been doing it for 40 years, and he's one of the best, and he can sometimes catch 70 or 80 percent more than somebody who doesn't know what they're doing ... I've put [fewer] years into it and I'm still learning every day ... so [an MPA here] is going to screw me up, because then I have to go out here and re-learn. (Fisher 2)
\end{abstract}

\section{Subjective well-being}

Subjective well-being refers to how people feel about what they have and what they do (McGregor 2007, Coulthard et al. 2015). Results show that the Musquash MPA enhanced place identity for the surrounding land-based community, but not for fishers. For example, informants at Musquash expressed an increase in community pride as a result of the MPA, but fishers expressed no such connections. However, fishers did feel that place identity would be negatively impacted by an MPA at HH/WI through a 
loss of cultural and familial heritage. If an MPA caused some access loss to the fishery, it would alter the ability of families to continue fishing in the same places or fisheries as their forebears. Fishers often used the term "way of life" (see Trimble and Johnson 2013, Santos 2015) when discussing place identity, expressing the importance of fishing as part of their identity.

\section{[Fishing] is something I look forward to doing. It's not a matter of money, it's a way of life. (Fisher 7)}

Equity was also discussed at length by participants in this research. Although Musquash was described as "win-win," participants reported that inshore fishers would most likely experience more overall costs of MPA implementation compared with other industries or sectors. They expected marine tourism to benefit because of the marketing benefits of an MPA (e.g., clean environment), and other large industries (e.g., aquaculture and shipping) to avoid impact by lobbying the government. Certain industries are perceived as very powerful in New Brunswick, such as aquaculture, which has developed into a monopolistic industry with significant control over marine space and resources (Knott and Neis 2017).

\section{I don't think that the government of Canada has the fortitude to address the pulp and paper industry or the aquaculture industry, or any of those things. I think the fishing industry is an easy low-hanging fruit to target. (Informant 5)}

Fishers also discussed their need to exercise adaptability within a dynamic environment, especially in the context of climate change. Many fishers recounted how their adaptability in the past had enabled them to continue fishing when faced with major unpredictable changes, e.g., entering into new fisheries when others declined. Participants felt that MPAs are too static and permanent to respond to changing social and ecological conditions, particularly because of the lengthy regulatory process that would be required to amend MPA regulations that stipulate zones and allowable human activities. Fishers expressed concerns about being "locked in" to current conditions by an MPA. For example, if all fisheries within an MPA were restricted except for lobster, there would no longer be a fallback species in that area if lobster stocks declined. Some conservation approaches do address the dynamic nature of the ocean, such as adaptive spatial planning (Mills et al. 2015) and dynamic oceans management (Maxwell et al. 2015). However, there are still significant challenges associated with these approaches, e.g., legislative barriers, and they may come with tradeoffs, because MPAs must be implemented for the long term to meet international standards (see Day et al. 2012) and to assess conservation effectiveness over time (Mills et al. 2015).

\section{Ecological resilience}

Ecological resilience refers to the ability of an ecological system to absorb disturbances and reorganize while retaining its structure and function (Walker et al. 2004). Participants generally recognized that MPAs can result in ecological benefits, but fishers expressed that this would come at the cost of other well-being trade-offs. Most participants discussed specific disturbances (i.e., threats) to the environment rather than attributes of resilience (i.e., things that help the environment buffer or cope with those threats). For example, participants commonly discussed the ecological outcomes of MPAs as a result of restricting commercial fishing and other industrial pressures, but just under half of the participants either could not identify attributes of resilience or said there were none. In practice, this could mean the concept of ecological resilience is difficult to elicit or less salient than other ecological ideas. We speculate that fishers may conceptualize ecosystem change incrementally over time, e.g., "boom and bust," rather than as absorbing disturbances and reorganizing. Participants who did discuss attributes of resilience spoke more broadly about protecting aspects of natural capital, such as habitat, productivity, and biodiversity.

In terms of disturbances, Musquash was perceived to have effectively avoided the impacts of "heavier" industrial development that may have otherwise damaged ecological conditions and undermined resilience, e.g., aquaculture and energy development. For example, a proposal for an aquaculture site adjacent to Musquash in 2008 was terminated partly because of its proximity to the MPA. Participants reflected on whether an MPA at HH/WI would provide clout against future industrial development. However, many reasoned that the political power of other industries would make them immune to MPA restrictions, perpetuating ineffective and inconsistent environmental protections. This is reflected in Canada's current legislative context in which a variety of resource extraction activities are permitted in designated MPAs (CPAWS 2015). Moreover, the inshore fishery was perceived to already be adequately sustainable by fishers, and some felt that effort displaced from an MPA would result in overfishing in adjacent areas. These concerns resonate with experiences elsewhere in which effort redistributed from MPAs has resulted in increased pressure on fish stocks outside MPA boundaries (Suuronen et al. 2010, Abbott and Haynie 2012).

Participants also often initiated discussions about scale and the corresponding implications for ecological resilience. For example, participants discussed upstream, land-based, and aerial sources of contamination that could influence ecological conditions within MPAs. Conservation lands adjacent to the Musquash MPA, some perceived to have been catalyzed by the designation of the MPA, were seen as useful for addressing some of these concerns by providing a buffer zone between sources of contamination on land and waters within the MPA. Such concerns about land-ocean interactions in the context of effectiveness of MPAs remain a key challenge (Álvarez-Romero et al. 2011, Kerr et al. 2014) and serve as a context in which SEWB interactions occur.

In terms of temporal scales, moreover, the perceived inflexibility of MPA regulations was also identified by participants as a limitation of MPAs being able to protect dynamic ecosystems through time. In this regard, there is an important alignment between people's understanding of dynamic ecological conditions and the need for governance processes to accommodate that dynamism if SEWB is to be maintained (see Perry et al. 2010, Chaffin et al. 2014). As summarized by one participant:

One of the problems with a marine protected area is that it's set, and the ocean shifts, particularly around climate change. Temperature shifts, and fish stocks shift ... Lack of movement when you're in an entirely moving environment might be too restrictive. (Informant 8) 


\section{Governance implications for marine protected areas}

We build on the results from our first research objective and identify crosscutting governance themes from the perceived costs of MPAs (Fig. 3). One attribute, "markets," was perceived partially as a cost (Table 4), but it did not correspond to any of these themes and was therefore omitted from Figure 3. We present these themes as three key insights to enhance the effectiveness of MPA governance: (1) displacement has multidimensional implications, (2) effective collaboration is critical for community support, and (3) several aspects of MPAs fit poorly with the social and ecological context.

Fig. 3. Thematic categorization of the perceived costs of marine protected areas.

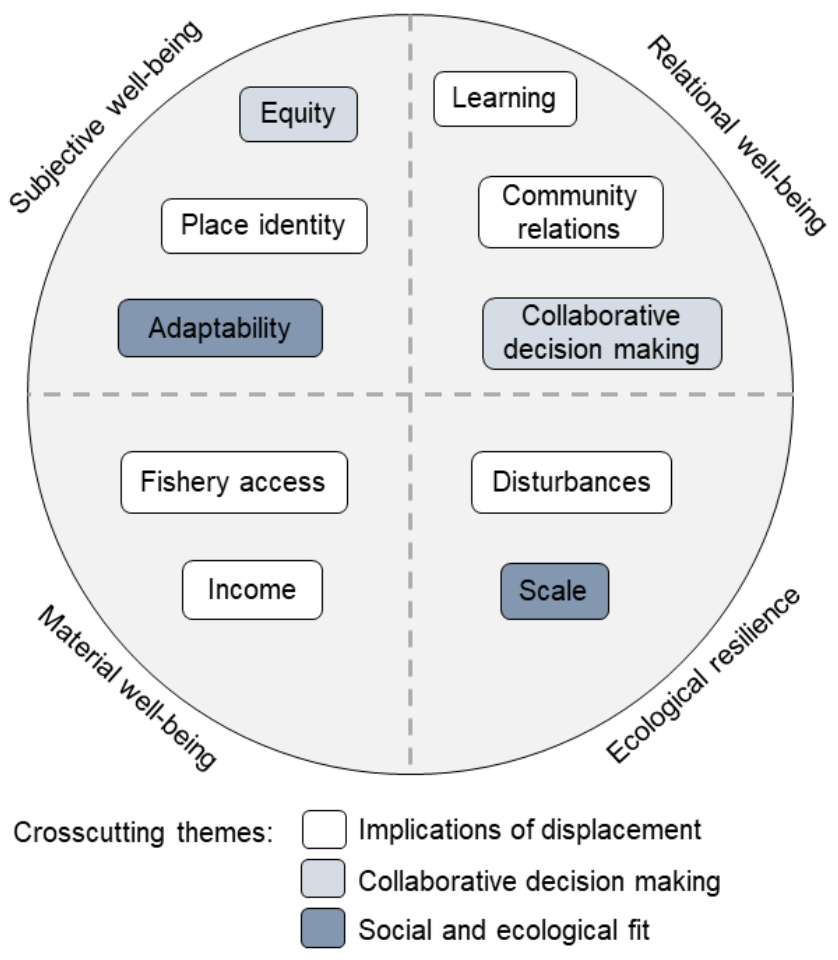

Displacement has multidimensional implications

Participants reported consequences of physical displacement that spanned material (e.g., income), relational (e.g., community relations), subjective (e.g., place identity), and ecological (e.g., disturbances) attributes of well-being. Figure 4 represents scenarios that participants described of what would happen if fishers were displaced from an area by an MPA, highlighting three key governance implications.

First, concern about displacement results in a suite of other apprehensions about MPAs among the fishing community. Displacement is the source of 6 of the 11 SEWB attributes that were perceived as costs. In the case of Musquash where there was no displacement, only 1 attribute was perceived as a cost. Second, access to the fishery has implications beyond the material ability to catch fish, across relational, subjective, and ecological dimensions of well-being. Participants elaborated that nonfishers often assumed that moving to new fishing grounds was relatively easy with mobile gear. In reality, learning, place identity, income, community relations, and fishery resources can all be influenced when a fisher relocates their fishing effort. Third, displacement can undermine conservation objectives and has the potential to cause further displacement. For example, it could cause overfishing in adjacent areas, leading to depleted stocks and presumably further displacement of effort. Fishers in the past have redistributed their effort in the Bay of Fundy in response to declining stocks (e.g., Clark et al. 1998), although the redistribution of effort as a result of MPAs is complex and depends on individual fishers and the fisheries in which they take part (Horta e Costa et al. 2013).

Effective collaboration is critical for community support

The current approach to MPA decision making does not align with the stated needs and priorities of the inshore fishing community. Fishers wanted more opportunities to collaborate in MPA decision making. Many fishers felt that they had been left out of planning to date, even though there were no formal plans on the table for a new MPA in their fishing area, and that the topdown government mandate was problematic.

When they put a marine protected zone in place, who are they asking? They're taking science, they're having these meetings, but I don't see them right from the ground floor. As I said, they've already got a map out there that's showing some of these places they're considering for a marine protected area. Who did they ask? It wasn't a fisherman that knew about it until the rumor trickled down that they were considering marine protected areas, and they've already got [EBSAs] on a map. Who are they asking? (Fisher 19)

When asked what should be changed about the MPA process to date, the most common recommendation among participants at $\mathrm{HH} / \mathrm{WI}$ was to increase collaboration in the planning process. Methods of community engagement were suggested, such as seeking local knowledge to identify areas of ecological and socioeconomic value. There are examples of this in other contexts. For instance, local knowledge has been used to map fishing effort and identify areas of economic importance to consider in MPA development in the United Kingdom (Szostek et al. 2017). As one participant noted:

It might surprise you to how much a fisherman can help them in this process, if they could only put some trust in them and ask them the questions. (Fisher 19)

Clear and transparent communication is essential to build trust, ease suspicions, and collaborate effectively. Participants were frustrated that the full purpose and meaning of an MPA designation was still unclear, and some expressed concerns that these decisions could be made behind closed doors. Skepticism has been entrenched by some government messaging promoting the benefits of MPAs to the fishery, e.g., proliferation of fish stocks, that are widely believed to be unrealistic outcomes in the Bay of Fundy.

Further, MPAs were perceived as unfair based on who is able to participate in decision making and not just final MPA outcomes. Ideas about who should be able to influence MPA decision making were varied, including arguments of historical precedence, adjacency, and common-pool resources. For example: 
Fig. 4. Consequences of marine protected area (MPA) displacement on attributes of social-ecological well-being. Solid arrows represent scenarios described by participants, and dashed arrows represent inferred relationships between attributes.

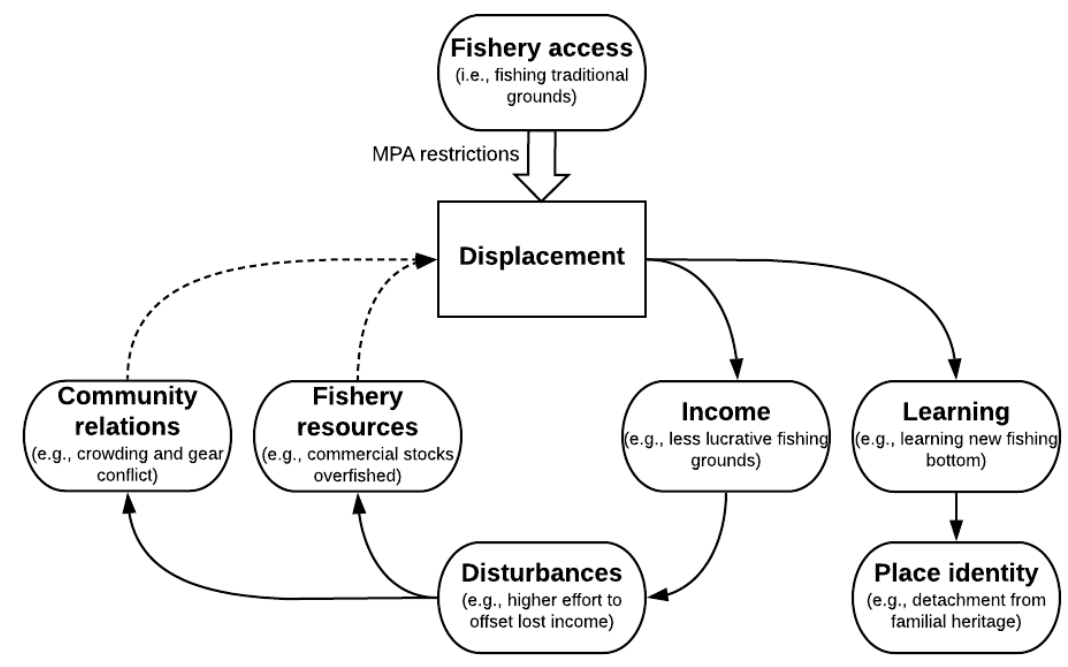

I still feel it's our fishery, and I say "our fishery" as a fisherman. It belongs to the fishermen. (Fisher 4)

It's a natural resource. It's a public resource, and it's not yours. It's also mine, and the part that's mine, I'd like to see marine protected areas. (Informant 3 )

Aspects of marine protected areas fit poorly with the social and ecological context

Participants reported that MPAs do not align with the underlying social and ecological systems in Southwest New Brunswick's fishing community in a variety of ways. Poor social fit was clear from participant dissatisfaction with decision making, as discussed previously. Fishers indicated that their primary wellbeing priorities were related to improving fisheries management and enforcement rather than advancing new conservation interests. Participants commonly reported that MPAs would likely reduce the number of options for fishing (e.g., location, species, and gear types) and thereby reduce the ability of fishers to exercise adaptability, a critical attribute of fisher well-being in the context of accelerated change. Many participants also noted that MPAs do not account for or reward existing and ongoing efforts toward sustainability in the fishery.

Given that the fishermen organizations here have been working really hard to create more sustainable fisheries and more sustainable communities, it seems like there's a convergence of some really positive things happening. So instead of just saying, "okay well forget all that, and we're just going to plop down an MPA here," it seems to me more sensible to take a more nuanced approach. (Informant 5)

Ecological fit was also discussed by participants, particularly surrounding issues of temporal and spatial scales (see Epstein et al. 2015). Ecological conditions are dynamic, but MPAs were perceived as inflexible conservation tools that would constrain the ability to respond quickly to changes in the ecosystem. Participants also noted that many ecological processes occur at larger scales than within the boundaries of an MPA (e.g., migratory species), and that MPAs could still be impacted by transboundary pollution.

\section{DISCUSSION}

We develop and apply a framework for SEWB to holistically understand the social implications of MPAs and reveal key governance insights for MPA decision makers in the Bay of Fundy (Table 5). Our framework for SEWB offers a heuristic for examining the linkages among MPAs and multiple dimensions of well-being. Our analysis has revealed a relatively broad set of wellbeing attributes linked to MPAs (Table 4) in comparison with narrower conceptualizations of well-being in the literature (e.g., Gjertsen 2005, Mascia et al. 2010, Stevenson et al. 2013, Ngoc 2018).

Our findings reveal the multidimensional (i.e., material, relational, subjective, and ecological) consequences of fisher displacement from MPAs, adding qualitative depth and social aspects of displacement to the literature that have been previously underrecognized. Previous research has focused almost exclusively on economic costs of displacement (e.g., Stevenson et al. 2013, Chollett et al. 2016) and the ecological implications of reallocating effort into smaller areas (e.g., Abbott and Haynie 2012, Vaughan 2017). Our findings emphasize but are not limited to the relational and subjective contributions of SEWB. We demonstrate that less tangible attributes (e.g., learning and place identity), which have often been neglected in social research on MPAs (Sowman and Sunde 2018), can be linked to displacement. However, a different suite of linked SEWB issues could manifest in other cases, highlighting the importance of a systematic approach. 
Table 5. Key implications for marine protected area (MPA) governance from social-ecological well-being insights. DFO, Fisheries and Oceans Canada.

\begin{tabular}{|c|c|}
\hline Well-being Insights & Key Governance Implications \\
\hline $\begin{array}{l}\text { Implications of } \\
\text { displacement }\end{array}$ & $\begin{array}{l}\text { Displacement is an entry point for addressing multiple other concerns about MPAs. } \\
\text { Consequences of displacement are multidimensional, and as such, should be conceptualized holistically. } \\
\text { MPAs are but one source of displacement and must be considered in the context of the broader social and ecological } \\
\text { systems. }\end{array}$ \\
\hline $\begin{array}{l}\text { Collaborative decision } \\
\text { making }\end{array}$ & $\begin{array}{l}\text { Effective collaboration with the inshore fishing community is essential, but not necessarily sufficient, for gaining support } \\
\text { for MPAs. } \\
\text { The clarity and transparency of communication about MPAs has implications for community trust in DFO and support } \\
\text { for MPAs. } \\
\text { Explicit attention to equity in terms of both process, i.e., who gets to make decisions, and outcomes, i.e., how benefits and } \\
\text { costs are distributed across stakeholders, may address perceived unfairness of MPAs. }\end{array}$ \\
\hline Social and ecological fit & $\begin{array}{l}\text { As they stand, several aspects of MPAs have poor social and ecological fit in Southwest New Brunswick. } \\
\text { MPAs do not take existing social structures into account and may not be flexible enough to accommodate dynamic } \\
\text { ecosystems and issues of scale. } \\
\text { Fit may be enhanced through effective collaboration, aligning MPAs with fishers' priorities, more adaptive governance, or } \\
\text { alternative conservation models. }\end{array}$ \\
\hline
\end{tabular}

In practice, these results indicate that expecting enough fish spillover (Halpern et al. 2004, Cinner et al. 2014, Chollett et al. 2016), mobility (Smith et al. 2010), or financial compensation (Sen 2010, Chollett et al. 2016) to offset the costs of displacement may not adequately address the well-being of fishers. Further, the cumulative implications of other sources of displacement, e.g., aquaculture (Wiber et al. 2012), could intensify or alter these consequences. Addressing displacement would ease many other apprehensions about MPAs in the fishing community, but displacement may be unavoidable given the purpose of MPAs to protect ecosystems from human disturbances, including commercial fisheries. As such, decision makers should at least recognize the broader implications of displacement and consider MPAs systemically, in the context of marine spatial planning and integrated management (Cicin-Sain and Belfiore 2005, Agardy et al. 2011).

Perceptions about the need for effective collaboration in the Bay of Fundy are well aligned with existing best practice approaches, including good governance principles for protected areas (e.g., participation, transparency, and legitimacy; Lockwood 2010, Lausche 2011); principles of collaboration and transparency in Canadian policy directives for MPAs (DFO 2005, 2011); and Aichi Target 11, which stipulates "equitably managed" protected areas. These principles have recently been reaffirmed in review processes advising the Canadian government to undertake meaningful, transparent, and accessible consultations with local communities throughout MPA processes (Bujold and Simon 2018, FOPO 2018). However, findings from our case study suggest that these principles have not materialized in consultations to date, or that there are different perspectives among stakeholder groups about what constitutes effective collaboration and when collaboration should occur. Addressing these inconsistencies is critical for SEWB and MPA governance, given the fishing community's general resistance to new MPAs in the Bay of Fundy, as well as existing perceptions about lack of participation in regional marine governance (Stephenson 2012). Fishers have reported insufficient participation in other cases (Pita et al. 2011), and perceptions of inequity and overselling the benefits of MPAs can further undermine long-term support for conservation initiatives (Halpern et al. 2013, Cinner et al. 2014).
Collaborative approaches involve the sharing of power between actors (Berkes 2009). Existing power differentials, such as those perceived by participants, can influence who becomes "winners and losers" (Jentoft 2017) and could conceivably undermine collaborative efforts. Evenly distributing the benefits and costs of MPA outcomes and simultaneously maximizing conservation benefits may not be possible (Halpern et al. 2013). However, systematically addressing perceived well-being/ecological tradeoffs with stakeholders could reveal which trade-offs are more acceptable than others and make deliberation over "hard choices" more transparent. For example, Daw et al. (2015) demonstrated that participatory deliberation among stakeholders has the capacity to reveal different types of trade-offs with varying levels of acceptability. In the Southwest New Brunswick case, offering fishers more opportunity to contribute their knowledge, as has been done in previous collaborations between fishers and other stakeholders (e.g., Maillet et al. 2019), might make certain tradeoffs more acceptable. Pita et al. (2011) found that fishers were more supportive of MPAs when the MPA's primary objectives were related to fisheries management rather than conservation. Our findings suggest that thinking in terms of fisheries management, e.g., commercial stocks, would align more strongly with fishers" well-being priorities. The "bequest value" of MPAs (Chaigneau and Brown 2016) and considering future generations may also be salient, given that in Southwest New Brunswick the fishing way of life is strongly tied to place identity and family heritage across generations.

Improving the fit of MPAs may also require more adaptive governance to increase the capacity to respond to changing social and ecological conditions. This would entail organizing actors and processes to be more flexible and to learn from and respond to change (Folke et al. 2005, Steelman 2015). A certain degree of adaptability does exist within current MPA governance (e.g., adaptive management guides the management of Musquash; DFO 2008), but some design features of MPAs are set in regulation (e.g., delineation of zones). Given these considerations, as well as fishers' apprehension about being locked into environmental conditions by an MPA, alternatives to conventional MPAs should be explored, including voluntary measures, spatial-temporal fishery closures (e.g., Kincaid and 
Rose 2014), community-based management (e.g., Ferse et al. 2010), or even more adaptive MPA models (e.g., Game et al. 2009, Mills et al. 2015). However, alternatives should not be used to justify half-measures (e.g., Lemieux et al. 2019), and some alternatives may not count toward $10 \%$ coverage commitments. There is potentially a tension between objectives related to "fit" and the extent of area designated. Such tensions need to consider well-being/resilience trade-offs.

In addition to providing MPA governance insights, this research empirically demonstrates the value of integrating social wellbeing and ecological resilience (Armitage et al. 2012, Loring et al. 2016). The framework for SEWB generated results that were holistic and applied the strengths of both well-being and resilience thinking. For example, the framework made normative aspects of MPAs explicit, by bringing considerations of equity and different values about the ecosystem to light, while also highlighting the challenge of thinking through elements of ecological resilience (e.g., scale) and not just ecological outcomes. Our approach also contextualized the specific interactions among MPAs, the inshore fishing community, and the ecosystem. Insight into perceived trade-offs and linkages among the ecological value of MPAs and other social costs have been emphasized. Ultimately, the framework is novel in its integrative ability, which has generated additional governance insights to enhance MPA outcomes. However, we do note that key insights reflect only differences among the inshore fishing community and all other stakeholders, and that perceptions of well-being can vary within and across multiple different stakeholder groups (e.g., Britton and Coulthard 2013, Pita et al. 2013). Nevertheless, the framework could be applied to examine trade-offs and normative aspects of MPAs across or within additional stakeholder groups (e.g., tourism and other industries), as well as to assess broader access issues in the marine environment (e.g., Bennett et al. 2018).

\section{CONCLUSION}

Social well-being can influence the long-term outcomes of MPAs (Chaigneau and Daw 2015, Sowman and Sunde 2018). Using an SEWB approach, we found that many social outcomes of MPA network expansion were perceived as costs by the inshore fishing community of Southwest New Brunswick, across material (e.g., access), relational (e.g., community relations), subjective (e.g., adaptability), and ecological (e.g., scale) dimensions. We contribute three major SEWB insights that may be used by decision makers to enhance the effectiveness of MPA governance. These insights are relevant to our case study context but have broader application to other marine systems where MPAs are being developed. First, decision makers must address potential displacement in holistic and systemic terms, because it is the source of multiple other concerns about MPAs across all four dimensions of fisher well-being. Second, fishers feel sidelined by MPA processes despite well-recognized principles of good governance. Decision makers should consider how communities define effective collaboration and create transparent opportunities for participation to improve perceptions of fairness. Third, several aspects of MPAs have poor fit with the underlying social and ecological dynamics in Southwest New Brunswick. This may be rectified through effective collaboration, alignment with fishers' priorities, and more adaptive governance.
Our research contributes to the growing literature on the wellbeing implications of conservation initiatives (Milner-Gulland et al. 2014, Woodhouse et al. 2015) and demonstrates that there can be tensions between international targets for conservation and local priorities. Ultimately, MPAs are one tool for conserving biodiversity and ecosystem function (DFO 2011). Attaining coverage goals will not be meaningful if MPAs are not effective (Pressey et al. 2017). How and with whom MPAs are designed will determine their outcomes. As we show, greater attention is needed to understand the differentiated manner in which social well-being and ecological resilience intersect among coastal communities adjacent to MPAs. Governing MPAs with sensitivity to well-being/ecological trade-offs will determine how Aichi Target 11 is achieved and inform pathways for the post-2020 global biodiversity framework.

Responses to this article can be read online at: http://www.ecologyandsociety.org/issues/responses. php/10995

\begin{abstract}
Acknowledgments:
We thank all research participants and communities in Southwest New Brunswick for their support and participation in our work. This research was supported by the Social Sciences and Humanities Research Council of Canada (SSHRC) through the OceanCanada Partnership, in addition to individual SSHRCand Ontario Graduate Scholarship grants to I. Brueckner-Irwin.
\end{abstract}

\section{LITERATURE CITED}

Abbott, J. K., and A. C. Haynie. 2012. What are we protecting? Fisher behavior and the unintended consequences of spatial closures as a fishery management tool. Ecological Applications 22 (3):762-777. http://dx.doi.org/10.1890/11-1319.1

Agardy, T., G. G. Notarbartolo di Sciara, and P. Christie. 2011. Mind the gap: addressing the shortcomings of marine protected areas through large scale marine spatial planning. Marine Policy 35(2):226-232. http://dx.doi.org/10.1016/j.marpol.2010.10.006

Allen, C. R., D. G. Angeler, A. A. Garmestani, L. H. Gunderson, and C. S. Holling. 2014. Panarchy: theory and application. Ecosystems 17:578-589. http://dx.doi.org/10.1007/s10021-013-9744-2

Álvarez-Romero, J. G., R. L. Pressey, N. C. Ban, K. VanceBorland, C. Willer, C. J. Klein, and S. D. Gaines. 2011. Integrated land-sea conservation planning: the missing links. Annual Review of Ecology, Evolution, and Systematics 42:381-409. http://dx.doi. org/10.1146/annurev-ecolsys-102209-144702

Angulo-Valdés, J. A., and B. G. Hatcher. 2010. A new typology of benefits derived from marine protected areas. Marine Policy 34(3):635-644. http://dx.doi.org/10.1016/j.marpol.2009.12.002

Armitage, D., C. Béné, A. T. Charles, D. Johnson, and E. H. Allison. 2012. The interplay of well-being and resilience in applying a social-ecological perspective. Ecology and Society 17 (4):15. http://dx.doi.org/10.5751/ES-04940-170415 
Armitage, D., A. Charles, and F. Berkes. 2017. Towards transformative change in the coastal commons. Pages 1-21 in D. Armitage, A. Charles and F. Berkes, editors. Governing the coastal commons: communities, resilience and transformation. Routledge, New York, New York, USA. https://doi.org/10.4324/9781315688480-1

Barnett, A. J. 2018. Recommendations for full-spectrum sustainability in Canadian lobster integrated management plans based on socioeconomic analysis of Barrington, Nova Scotia. Ecology and Society 23(1):36. http://dx.doi.org/10.5751/ ES-09981-230136

Bennett, N. J. 2016. Using perceptions as evidence to improve conservation and environmental management. Conservation Biology 30(3):582-592. http://dx.doi.org/10.1111/cobi.12681

Bennett, N. J., and P. Dearden. 2014. From measuring outcomes to providing inputs: governance, management, and local development for more effective marine protected areas. Marine Policy 50A:96-110. http://dx.doi.org/10.1016/j.marpol.2014.05.005

Bennett, N. J., M. Kaplan-Hallam, G. Augustine, N. Ban, D. Belhabib, I. Brueckner-Irwin, A. Charles, J. Couture, S. Eger, L. Fanning, P. Foley, A. M. Goodfellow, L. Greba, E. Gregr, D. Hall, S. Harper, B. Maloney, J. McIsaac, W. Ou, E. Pinkerton, D. Porter, R. Sparrow, R. Stephenson, A. Stocks, U. R. Sumaila, T. Sutcliffe, and M. Bailey. 2018. Coastal and Indigenous community access to marine resources and the ocean: a policy imperative for Canada. Marine Policy 87:186-193. http://dx.doi.org/10.1016/j. marpol.2017.10.023

Berdej, S., and D. Armitage. 2016. Bridging for better conservation fit in Indonesia's coastal-marine systems. Frontiers in Marine Science 3:101. http://dx.doi.org/10.3389/fmars.2016.00101

Berkes, F. 2009. Evolution of co-management: role of knowledge generation, bridging organizations and social learning. Journal of Environmental Management 90(5):1692-1702. http://dx.doi. org/10.1016/j.jenvman.2008.12.001

Biedenweg, K., K. Stiles, and K. Wellman. 2016. A holistic framework for identifying human wellbeing indicators for marine policy. Marine Policy 64:31-37. http://dx.doi.org/10.1016/j. marpol.2015.11.002

Boonzaier, L., and D. Pauly. 2016. Marine protection targets: an updated assessment of global progress. Oryx 50(1):27-35. http:// dx.doi.org/10.1017/S0030605315000848

Britton, E., and S. Coulthard. 2013. Assessing the social wellbeing of Northern Ireland's fishing society using a three-dimensional approach. Marine Policy 37:28-36. http://dx.doi.org/10.1016/j. marpol.2012.04.011

Brown, K. 2014. Global environmental change I: a social turn for resilience? Progress in Human Geography 38(1):107-117. http://dx. doi.org/10.1177/0309132513498837

Bujold, R., and M. Simon. 2018. Final report of the National Advisory Panel on Marine Protected Area Standards. Fisheries and Oceans Canada, Ottawa, Ontario, Canada. [online] URL: http:// www.dfo-mpo.gc.ca/oceans/publications/advisorypanelcomiteconseil/2018/finalreport-rapportfinal/page01-eng.html

Buzeta, M.-I. 2014. Identification and review of ecologically and biologically significant areas in the Bay of Fundy. Canadian
Science Advisory Secretariat Research Document 2013/065. Fisheries and Oceans Canada, Ottawa, Ontario, Canada. [online] URL: http://waves-vagues.dfo-mpo.gc.ca/Library/359756.pdf

Canadian Parks and Wilderness Society (CPAWS). 2015. Dare to be deep: are Canada's marine protected areas really !? CPAWS, Ottawa, Ontario, Canada.

Chaffin, B. C., H. Gosnell, and B. A. Cosens. 2014. A decade of adaptive governance scholarship: synthesis and future directions. Ecology and Society 19(3):56. http://dx.doi.org/10.5751/ ES-06824-190356

Chaigneau, T., and K. Brown. 2016. Challenging the win-win discourse on conservation and development: analyzing support for marine protected areas. Ecology and Society 21(1):36. http:// dx.doi.org/10.5751/ES-08204-210136

Chaigneau, T., and T. M. Daw. 2015. Individual and village-level effects on community support for marine protected areas (MPAs) in the Philippines. Marine Policy 51:499-506. http://dx.doi. org/10.1016/j.marpol.2014.08.007

Chan, C. 2017. Ecosystem services and social wellbeing linkages: the impact of a marine protected area in Bluefields, Jamaica. Thesis. University of Waterloo, Waterloo, Ontario, Canada. [online] URL: http://hdl.handle.net/10012/12005

Charles, A., and L. Wilson. 2009. Human dimensions of marine protected areas. ICES Journal of Marine Science 66:6-15. http:// dx.doi.org/10.1093/icesjms/fsn182

Chollett, I., S. J. Box, and P. J. Mumby. 2016. Quantifying the squeezing or stretching of fisheries as they adapt to displacement by marine reserves. Conservation Biology 30(1):166-175. http://dx. doi.org/10.1111/cobi.12573

Cicin-Sain, B., and S. Belfiore. 2005. Linking marine protected areas to integrated coastal and ocean management: a review of theory and practice. Ocean \& Coastal Management 48:847-868. http://dx.doi.org/10.1016/j.ocecoaman.2006.01.001

Cinner, J. E., T. Daw, C. Huchery, P. Thoya, A. Wamukota, M. Cedras, and C. Abunge. 2014. Winners and losers in marine conservation: fishers' displacement and livelihood benefits from marine reserves. Society and Natural Resources 27:994-1005. http://dx.doi.org/10.1080/08941920.2014.918229

Clark, D., J. Neilson, and P. Hurley. 1998. Shifts in fishing effort, commercial landings and resource distribution for cod, haddock, pollock and white hake in NAFO Division $4 X$. Canadian Stock Assessment Secretariat Research Document 98/58. Fisheries and Oceans Canada, Ottawa, Ontario, Canada.

Coffen-Smout, S., D. Shervill, D. Sam, C. Denton, and J. Tremblay. 2013. Mapping inshore lobster landings and fishing effort on a Maritimes region modified grid system. Canadian Technical Report of Fisheries and Aquatic Sciences 3024. Fisheries and Oceans Canada, Ottawa, Ontario, Canada. [online] URL: $\underline{\text { http:// }}$ www.dfo-mpo.gc.ca/library/348229.pdf

Convention on Biological Diversity (CBD). 2010. COP 10 decision X/2: strategic plan for biodiversity 2011-2020. United Nations Environment Programme, Nagoya, Japan. [online] URL: https://www.cbd.int/decision/cop/?id=12268 
Cote, M., and A. J. Nightingale. 2012. Resilience thinking meets social theory: situating social change in socio-ecological systems (SES) research. Progress in Human Geography 36(4):475-489. http://dx.doi.org/10.1177/0309132511425708

Coulthard, S., D. Johnson, and J. A. McGregor. 2011. Poverty, sustainability and human wellbeing: a social wellbeing approach to the global fisheries crisis. Global Environmental Change 21 (2):453-463. http://dx.doi.org/10.1016/j.gloenvcha.2011.01.003

Coulthard, S., N. Paranamana, L. Sandaruwan, R. Manimohan, R. Maya, O. Amarasinghe, D. Koralgama, E. Britton, C. Bene, J. A. McGregor, N. Pouw, C. Abunge, P. Mbatha, R. Ramachandran, P. Ramachandran, and T. Daw. 2015. Exploring wellbeing in fishing communities: methods handbook. University of Northumbria, Newcastle upon Tyne, UK. [online] URL: https://www.researchgate.net/publication/283046223 Exploringwellbeing in fishing communities Methods handbook Output from the ESRC_WellFish_project_Ref_no_ESI0096042

Cretney, R. 2014. Resilience for whom? Emerging critical geographies of socio-ecological resilience. Geography Compass 8 (9):627-640. http://dx.doi.org/10.1111/gec3.12154

Daw, T. M., S. Coulthard, W. W. L. Cheung, K. Brown, C. Abunge, D. Galafassi, G. D. Peterson, T. R. McClanahan, J. O. Omukoto, and L. Munyi. 2015. Evaluating taboo trade-offs in ecosystems services and human well-being. Proceedings of the National Academy of Sciences of the United States of America 112 (22):6949-6954. http://dx.doi.org/10.1073/pnas.1414900112

Day, J., N. Dudley, M. Hockings, G. Holmes, D. Laffoley, S. Stolton, and S. Wells. 2012. Guidelines for applying the IUCN protected area management categories to marine protected areas. International Union for Conservation of Nature and Natural Resources, Gland, Switzerland. [online] URL: https://cmsdata. iucn.org/downloads/uicn categoriesamp eng.pdf

Dehens, L. A., and L. M. Fanning. 2018. What counts in making marine protected areas (MPAs) count? The role of legitimacy in MPA success in Canada. Ecological Indicators 86:45-57. http:// dx.doi.org/10.1016/j.ecolind.2017.12.026

Devillers, R., R. L. Pressey, A. Grech, J. N. Kittinger, G. J. Edgar, T. Ward, and R. Watson. 2015. Reinventing residual reserves in the sea: are we favouring ease of establishment over need for protection? Aquatic Conservation: Marine and Freshwater Ecosystems 25:480-504. http://dx.doi.org/10.1002/aqc. 2445

Epstein, G., J. Pittman, S. M. Alexander, S. Berdej, T. Dyck, U. Kreitmar, K. J. Rathwell, S. Villamayor-Tomas, J. Vogt, and D. Armitage. 2015. Institutional fit and the sustainability of socialecological systems. Current Opinion on Environmental Sustainability 14:34-40. http://dx.doi.org/10.1016/j.cosust.2015.03.005

Ferraro, P. J., and R. L. Pressey. 2015. Measuring the difference made by conservation initiatives: protected areas and their environmental and social impacts. Philosophical Transactions of the Royal Society B: Biological Sciences 370(1681):20140270. http://dx.doi.org/10.1098/rstb.2014.0270

Ferse, S. C. A., M. M. Costa, K. S. Máñez, D. S. Adhuri, and M. Glaser. 2010. Allies, not aliens: increasing the role of local communities in marine protected area implementation. Environmental Conservation 37(1):23-34. http://dx.doi.org/10.1017/ $\underline{\mathrm{S} 0376892910000172}$
Fisheries and Oceans Canada (DFO). 2005. Canada's federal marine protected areas strategy. Communications Branch, DFO, Ottawa, Ontario, Canada. [online] URL: http://waves-vagues. dfo-mpo.gc.ca/Library/315822e.pdf

Fisheries and Oceans Canada (DFO). 2008. Musquash Estuary: a management plan for the marine protected area and administered intertidal area. Oceans, Habitat and Species at Risk Branch, DFO, Dartmouth, Nova Scotia, Canada. [online] URL: http://www. mar.dfo-mpo.gc.ca/folios/00264/docs/musquashmngtplan-eng.pdf

Fisheries and Oceans Canada (DFO). 2011. National framework for Canada's network of marine protected areas. DFO, Ottawa, Ontario, Canada. [online] URL: http://waves-vagues.dfo-mpo.gc. ca/Library/345207.pdf

Fisheries and Oceans Canada (DFO). 2018. Design strategies for a network of marine protected areas in the Scotian Shelf bioregion. Canadian Science Advisory Secretariat Science Advisory Report 2018/006. DFO, Ottawa, Ontario, Canada. [online] URL: http:// www.dfo-mpo.gc.ca/csas-sccs/Publications/SAR-AS/2018/2018 006eng.pdf

Folke, C. 2006. Resilience: the emergence of a perspective for social-ecological systems analyses. Global Environmental Change 16:253-267. http://dx.doi.org/10.1016/j.gloenvcha.2006.04.002

Folke, C. 2016. Resilience (republished). Ecology and Society 21 (4):44. http://dx.doi.org/10.5751/ES-09088-210444

Folke, C., T. Hahn, P. Olsson, and J. Norberg. 2005. Adaptive governance of social-ecological systems. Annual Review of Environment and Resources 30:441-473. http://dx.doi.org/10.1146/ annurev.energy.30.050504.144511

Game, E. T., M. Bode, E. McDonald-Madden, H. S. Grantham, and H. P. 2009. Dynamic marine protected areas can improve the resilience of coral reef systems. Ecology Letters 12:1336-1346. http://dx.doi.org/10.1111/j.1461-0248.2009.01384.X

Giakoumi, S., J. McGowan, M. Mills, M. Beger, R. H. Bustamante, A. Charles, P. Christie, M. Fox, P. GarciaBorboroglu, S. Gelcich, P. Guidetti, P. Mackelworth, J. M. Maina, L. McCook, F. Micheli, L. E. Morgan, P. J. Mumby, L. M. Reyes, A. White, K. Grorud-Colvert, and H. P. Possingham. 2018. Revisiting "success" and "failure" of marine protected areas: a conservation scientist perspective. Frontiers in Marine Science 5:223. http://dx.doi.org/10.3389/fmars.2018.00223

Gjertsen, H. 2005. Can habitat protection lead to improvements in human well-being? Evidence from marine protected areas in the Philippines. World Development 33:199-217. http://dx.doi. org/10.1016/j.worlddev.2004.07.009

Halpern, B. S., S. D. Gaines, and R. R. Warner. 2004. Confounding effects of the export of production and the displacement of fishing effort from marine reserves. Ecological Applications 14(4):1248-1256. http://dx.doi.org/10.1890/03-5136

Halpern, B. S., C. J. Klein, C. J. Brown, M. Beger, H. S. Grantham, S. Mangubhai, M. Ruckelshaus, V. J. Tulloch, M. Watts, C. White, and H. P. Possingham. 2013. Achieving the triple bottom line in the face of inherent trade-offs among social equity, economic return, and conservation. Proceedings of the National Academy of Sciences of the United States of America 110(15):6229-6234. http://dx.doi.org/10.1073/pnas.1217689110 
Hogg, K., P. Noguera-Méndez, M. Semitiel-García, T. Gray, and S. Young. 2017. Controversies over stakeholder participation in marine protected area (MPA) management: a case study of the Cabo de Palos-Islas Hormigas MPA. Ocean and Coastal Management 144:120-128. http://dx.doi.org/10.1016/j. ocecoaman.2017.05.002

Horta e Costa, B., M. I Batista, L. Gonçalves, K. Erzini, J. E. Caselle, H. N. Cabral, and E. J. Gonçalves. 2013. Fishers' behaviour in response to the implementation of a marine protected area. PLoS ONE 8(6):e65057. http://dx.doi. org/10.1371/journal.pone.0065057

Jentoft, S. 2017. Small-scale fisheries within maritime spatial planning: knowledge integration and power. Journal of Environmental Policy \& Planning 19(3):266-278. http://dx.doi. org/10.1080/1523908X.2017.1304210

Jones, P. J. S. 2008. Fishing industry and related perspectives on the issues raised by no-take marine protected area proposals. Marine Policy 32(4):749-758. http://dx.doi.org/10.1016/j. marpol.2007.12.009

Karst, H. 2017. Protected areas and ecotourism: charting a path toward social-ecological wellbeing. Dissertation. University of Waterloo, Waterloo, Ontario, Canada. [online] URL: https:// uwspace.uwaterloo.ca/handle/10012/11194

Kerr, S., K. Johnson, and J. C. Side. 2014. Planning at the edge: integrating across the land sea divide. Marine Policy 47:118-125. http://dx.doi.org/10.1016/j.marpol.2014.01.023

Kincaid, K. B., and G. A. Rose. 2014. Why fishers want a closed area in their fishing grounds: exploring perceptions and attitudes to sustainable fisheries and conservation 10 years post closures in Labrador, Canada. Marine Policy 46:84-90. http://dx.doi. org/10.1016/j.marpol.2014.01.007

Knott, C., and B. Neis. 2017. Privatization, financialization and ocean grabbing in New Brunswick herring fisheries and salmon aquaculture. Marine Policy 80:10-18. http://dx.doi.org/10.1016/j. marpol.2016.10.022

Koerber, A., and L. McMichael. 2008. Qualitative sampling methods: a primer for technical communicators. Journal of Business and Technical Communication 22(4):454-473. http://dx. doi.org/10.1177/1050651908320362

Kofinas, G. P. 2009. Adaptive co-management in social-ecological governance. Pages 77-101 in C. Folke, G. Kofinas, and F. S. Chapin, editors. Principles of ecosystem stewardship. Springer, New York, New York, USA. https://doi.org/10.1007/978-0-387-73033-2_4

Lapointe, G. 2013. Commercial fisheries: state of the Gulf of Maine report. Gulf of Maine Council on the Marine Environment and Fisheries and Oceans Canada, Dartmouth, Nova Scotia, Canada. [online] URL: http://www.gulfofmaine.org/2/wpcontent/uploads/2014/03/commercial-fisheries-theme-paper-webversion. pdf

Lausche, B. 2011. Guidelines for protected areas legislation. International Union for Conservation of Nature and Natural Resources, Gland, Switzerland. [online] URL: http://portals.iucn. org/library/sites/library/files/documents/eplp-081.pdf

Leleu, K., F. Alban, D. Pelletier, E. Charbonnel, Y. Letourneur, and C. F. Boudouresque. 2012. Fishers' perceptions as indicators of the performance of marine protected areas (MPAs). Marine Policy 36:414-422. http://dx.doi.org/10.1016/j.marpol.2011.06.002

Lemieux, C. J., P. A. Gray, R. Devillers, P. A. Wright, P. Dearden, E. A. Halpenny, M. Groulx, T. J. Beechey, and K. Beazley. 2019. How the race to achieve Aichi Target 11 could jeopardize the effective conservation of biodiversity in Canada and beyond. Marine Policy 99:312-323. http://dx.doi.org/10.1016/j.marpol.2018.10.029

Lockwood, M. 2010. Good governance for terrestrial protected areas: a framework, principles and performance indicators. Journal of Environmental Management 91:754-766. http://dx.doi. org/10.1016/j.jenvman.2009.10.005

Loring, P. A., M. S. Hinzman, and H. Neufeld. 2016. Can people be sentinels of sustainability? Identifying the linkages among ecosystem health and human well-being. FACETS 1:148-162. http://dx.doi.org/10.1139/facets-2016-0022

Lubchenco, J., and K. Grorud-Colvert. 2015. Making waves: the science and politics of ocean protection. Science 350 (6259):382-383. http://dx.doi.org/10.1126/science.aad5443

Mahajan, S. L., and T. Daw. 2016. Perceptions of ecosystem services and benefits to human well-being from community-based marine protected areas in Kenya. Marine Policy 74:108-119. http://dx.doi.org/10.1016/j.marpol.2016.09.005

Maillet, D. G. C., M. G. Wiber, and A. Barnett. 2019. Actions towards the joint production of knowledge: the risk of salmon aquaculture on American Lobster. Journal of Risk Research22:67-80. http://dx.doi.org/10.1080/13669877.2017.1351471

Mascia, M. B., C. A. Claus, and R. Naidoo. 2010. Impacts of marine protected areas on fishing communities. Conservation Biology 24(5):1424-1429. http://dx.doi.org/10.1111/j.1523-1739.2010.01523. $\underline{\mathrm{x}}$

Mascia, M. B., H. E. Fox, L. Glew, G. N. Ahmadia, A. Agrawal, M. Barnes, X. Basurto, I. Craigie, E. Darling, J. Geldmann, D. Gill, S. H. Rice, O. P. Jensen, S. E Lester, P. McConney, P. J. Mumby, M. Nenadovic, J. E. Parks, R. S. Pomeroy, and A. T. White. 2017. A novel framework for analyzing conservation impacts: evaluation, theory, and marine protected areas. Annals of the New York Academy of Sciences 1399:93-115. http://dx.doi. org/10.1111/nyas. 13428

Maxwell, S. M., E. L. Hazen, R. L. Lewison, D. C. Dunn, H. Bailey, S. J. Bograd, D. K. Briscoe, S. Fossette, A. J. Hobday, M. Bennett, S. Benson, M. R. Caldwell, D. P. Costa, H. Dewar, T. Eguchi, L. Hazen, S. Kohin, T. Sippel, and L. B. Crowder. 2015. Dynamic ocean management: defining and conceptualizing realtime management of the ocean. Marine Policy 58:42-50. http:// dx.doi.org/10.1016/j.marpol.2015.03.014

McGregor, J. A. 2007. Researching wellbeing: from concepts to methodology. Pages 316-350 in I. Gough and J. A. McGregor, editors. Wellbeing in developing countries: from theory to research. Cambridge University Press, New York, New York, USA.

McGregor, J. A. 2008. Wellbeing, poverty and conflict. WeD Policy Briefing 01/08. Wellbeing in Developing Countries (WeD) ESRC Research Group, University of Bath, Bath, UK.

McShane, T. O., P. D. Hirsch, T. C. Trung, A. N. Songorwa, A. Kinzig, B. Monteferri, D. Mutekanga, H. Van Thang, J. L. Dammert, M. Pulgar-Vidal, M. Welch-Devine, J. P. Brosius, P. 
Coppolillo, and S. O'Connor. 2011. Hard choices: making tradeoffs between biodiversity conservation and human well-being. Biological Conservation 144:966-972. http://dx.doi.org/10.1016/j. biocon.2010.04.038

Mills, M., R. Weeks, R. L. Pressey, M. G. Gleason, R.-L. EismaOsoria, A. T. Lombard, J. M. Harris, A. B. Killmer, A. White, and T. H. Morrison. 2015. Real-world progress in overcoming the challenges of adaptive spatial planning in marine protected areas. Biological Conservation 181:54-63. http://dx.doi.org/10.1016/j. biocon.2014.10.028

Milner-Gulland, E. J., J. A. McGregor, M. Agarwala, G. Atkinson, P. Bevan, T. Clements, T. Daw, K. Homewood, N. Kumpel, J. Lewis, S. Mourato, B. P. Fry, M. Redshaw, J. M. Rowcliffe, S. Suon, G. Wallace, H. Washington, and D. Wilkie. 2014. Accounting for the impact of conservation on human wellbeing. Conservation Biology 28(5):1160-1166. http://dx.doi. org/10.1111/cobi.12277

Ngoc, Q. T. K. 2018 Impacts on the ecosystem and human wellbeing of the marine protected area in $\mathrm{Cu}$ Lao Cham, Vietnam. Marine Policy 90:174-183. http://dx.doi.org/10.1016/j. marpol.2017.12.015 https://doi.org/10.1016/j.marpol.2017.12.015

Office of the Prime Minister of Canada (PMO). 2015. Minister of Fisheries, Oceans and the Canadian Coast Guard mandate letter (November 12, 2015). PMO, Ottawa, Ontario, Canada. [online] URL: https://pm.gc.ca/eng/archived-minister-fisheries-oceansand-canadian-coast-guard-mandate-letter

Office of the Prime Minister of Canada (PMO). 2018. Minister of Fisheries, Oceans and the Canadian Coast Guard mandate letter (August 28, 2018). PMO, Ottawa, Ontario, Canada. [online] URL: https://pm.gc.ca/eng/minister-fisheries-oceans-and-canadiancoast-guard-mandate-letter-august-28-2018

Ordoñez-Gauger, L., L. Richmond, S. Hackett, and C. Chen. 2018. It's a trust thing: assessing fishermen's perceptions of the California North Coast marine protected area network. Ocean and Coastal Management 158:144-153. http://dx.doi.org/10.1016/ j.ocecoaman.2018.03.034

Parliament of Canada. 2017. An Act to amend the Oceans Act and the Canada Petroleum Resources Act. House Government Bill C-55, 42nd Parliament, First session. House of Commons, Parliament of Canada, Ottawa, Ontario, Canada. [online] URL: https://www.parl.ca/LegisInfo/BillDetails.aspx?Language= $\underline{\text { E\&billId }=9041849}$

Parliament of Canada. 2018. An Act to amend the Fisheries Act and other Acts in consequence. House Government Bill C-68, 42nd Parliament, First session. House of Commons, Parliament of Canada, Ottawa, Ontario, Canada. [online] URL: https://www. parl.ca/LegisInfo/BillDetails.aspx?Language $=$ E\&billId $=9630814$

Perry, R. I., M. Barange, and R. E. Ommer. 2010. Global changes in marine systems: a social-ecological approach. Progress in Oceanography 87:331-337. http://dx.doi.org/10.1016/j.pocean.2010.09.010

Pita, C., G. J. Pierce, I. Theodossiou, and K. Macpherson. 2011. An overview of commercial fishers' attitudes towards marine protected areas. Hydrobiologia 670:289-306. http://dx.doi. org/10.1007/s10750-011-0665-9
Pita, C., I. Theodossiou, and G. J. Pierce. 2013. The perceptions of Scottish inshore fishers about marine protected areas. Marine Policy 37:254-263. http://dx.doi.org/10.1016/j.marpol.2012.05.007

Pomeroy, R. S., J. E. Parks, and L. M. Watson. 2004. How is your MPA doing? A guidebook of natural and social indicators for evaluating marine protected area management effectiveness. International Union for Conservation of Nature and Natural Resources, Gland, Switzerland. [online] URL: http://data.iucn. org/dbtw-wpd/edocs/PAPS-012.pdf https://doi.org/10.2305/IUCN. CH.2004.PAPS.1.en

Pressey, R. L., R. Weeks, and G. G. Gurney. 2017. From displacement activities to evidence-informed decisions in conservation. Biological Conservation 212A:337-348. http://dx. doi.org/10.1016/j.biocon.2017.06.009

Raudsepp-Hearne, C., G. D. Peterson, M. Tengö, E. M. Bennett, T. Holland, K. Benessaiah, G. K. MacDonald, and L. Pfeifer. 2010. Untangling the environmentalist's paradox: why is human well-being increasing as ecosystem services degrade? BioScience 60(8):576-589. http://dx.doi.org/10.1525/bio.2010.60.8.4

Rees, S. E., M. J. Attril, M. C. Austen, S. C. Mangi, and L. D. Rodwell. 2013a. A thematic cost-benefit analysis of a marine protected area. Journal of Environmental Management 114:476-485. http://dx.doi.org/10.1016/j.jenvman.2012.10.048 https:// doi.org/10.1016/j.jenvman.2012.10.048

Rees, S. E., S. Fletcher, S. C. Gall, L. A. Friedrich, E. L. Jackson, and L. D. Rodwell. 2014. Securing the benefits: linking ecology with marine planning policy to examine the potential of a network of marine protected areas to support human wellbeing. Marine Policy 44:335-341. http://dx.doi.org/10.1016/j.marpol.2013.09.027

Rees, S. E., L. D. Rodwell, S. Searle, and A. Bell. 2013b. Identifying the issues and options for managing the social impacts of marine protected areas on a small fishing community. Fisheries Research 146:51-58. http://dx.doi.org/10.1016/j.fishres.2013.04.003

Rossiter, J. S., and A. Levine. 2014. What makes a "successful" marine protected area? The unique context of Hawaii's fish replenishment areas. Marine Policy 44:196-203. http://dx.doi. org/10.1016/j.marpol.2013.08.022

Santos, A. N. 2015. Fisheries as a way of life: gendered livelihoods, identities and perspectives of artisanal fisheries in eastern Brazil. Marine Policy 62:279-288. http://dx.doi.org/10.1016/j.marpol.2015.09.007

Sen, S. 2010. Developing a framework for displaced fishing effort programs in marine protected areas. Marine Policy 34:1171-1177. http://dx.doi.org/10.1016/j.marpol.2010.03.017

Smith, M. D., J. Lynham, J. N. Sanchirico, and J. A. Wilson. 2010. Political economy of marine reserves: understanding the role of opportunity costs. Proceedings of the National Academy of Sciences of the United States of America 107(43):18300-18305. http://dx.doi.org/10.1073/pnas.0907365107

Sowman, M., and J. Sunde. 2018. Social impacts of marine protected areas in South Africa on coastal fishing communities. Ocean and Coastal Management 157:168-179. http://dx.doi. org/10.1016/j.ocecoaman.2018.02.013

Standing Committee on Fisheries and Oceans (FOPO). 2018. Healthy oceans, vibrant coastal communities: strengthening the 
Oceans Act marine protected areas' establishment process. 42nd Parliament, First session, Report 14. House of Commons, Parliament of Canada, Ottawa, Ontario, Canada. [online] URL: http://www.ourcommons.ca/DocumentViewer/en/42-1/FOPO/report-14/

Statistics Canada. 2017. Census profile, 2016 census. Catalogue no. 98-316-X2016001. Statistics Canada, Ottawa, Ontario, Canada. [online]: http://www12.statcan.gc.ca/census-recensement/2016/ dp-pd/prof/index.cfm?Lang $=\mathrm{E}$

Steelman, T. 2015. Adaptive governance. Pages 538-550 in C. Ansell and J. Torfing, editors. Handbook on theories of governance. Edward Elgar, Cheltenham, UK. https://doi.org/10.4337/97817$\underline{82548508.00056}$

Stephenson, R. L. 2012. A perspective on advancing ecosystem research for the Gulf of Maine. Pages 409-415 in R. Stephenson, J. Annala, J. Runge, and M. Hall-Arber, editors. Advancing an ecosystem approach in the Gulf of Maine. American Fisheries Society, Bethesda, Maryland, USA.

Stevenson, T. C., B. N. Tissot, and W. J. Walsh. 2013. Socioeconomic consequences of fishing displacement from marine protected areas in Hawaii. Biological Conservation 160:50-58. http://dx.doi.org/10.1016/j.biocon.2012.11.031

Suuronen, P., P. Jounela, and V. Tschernij. 2010. Fishermen responses on marine protected areas in the Baltic cod fishery. Marine Policy 34(2):237-243. http://dx.doi.org/10.1016/j. marpol.2009.07.001

Szostek, C. L., L. G. Murray, E. Bell, and M. J. Kaiser. 2017. Filling the gap: using fishers' knowledge to map the extent and intensity of fishing activity. Marine Environmental Research 129:329-346. http://dx.doi.org/10.1016/j.marenvres.2017.06.012

Thompson, C. 2010. The Gulf of Maine in context: state of the Gulf of Maine report. Gulf of Maine Council on the Marine Environment and Fisheries and Oceans Canada, Dartmouth, Nova Scotia, Canada. [online] URL: http://www.gulfofmaine. org/state-of-the-gulf/docs/the-gulf-of-maine-in-context.pdf

Trimble, M., and D. Johnson. 2013. Artisanal fishing as an undesirable way of life? The implications for governance of fishers' wellbeing aspirations in coastal Uruguay and southeastern Brazil. Marine Policy 37:37-44. http://dx.doi. org/10.1016/j.marpol.2012.04.002

Vaughan, D. 2017. Fishing effort displacement and the consequences of implementing marine protected area management - an English perspective. Marine Policy 84:228-234. http://dx.doi.org/10.1016/j.marpol.2017.07.007

Voyer, M., W. Gladstone, and H. Goodall. 2014. Understanding marine park opposition: the relationship between social impacts, environmental knowledge and motivation to fish. Aquatic Conservation: Marine and Freshwater Ecosystems 24:441-462. http://dx.doi.org/10.1002/aqc.2363

Walker, B., C. S. Holling, S. R. Carpenter, and A. Kinzig. 2004. Resilience, adaptability and transformability in social-ecological systems. Ecology and Society 9(2):5. https://doi.org/10.5751/ ES-00650-090205

Walker, B., and D. Salt. 2012. Resilience practice: building capacity to absorb disturbance and maintain function. Island, Washington, D.C., USA.
Walters, B. B. 2007. Competing use of marine space in a modernizing fishery: salmon farming meets lobster fishing on the Bay of Fundy. Canadian Geographer 51(2):139-159. http://dx.doi. org/10.1111/j.1541-0064.2007.00171.x

Walters, B. B., and M. Butler. 1995. Should we see lobster buoys bobbing in a marine park? Pages 205-213 in N. L. Shackell and J. H. M. Willison, editors. Marine protected areas and sustainable fisheries. Science and Management of Protected Areas Association, Wolfville, Nova Scotia, Canada.

Watson, M. S., and S. M. Hewson. 2018. Securing protection standards for Canada's marine protected areas. Marine Policy 95:117-122. http://dx.doi.org/10.1016/j.marpol.2018.07.002

Weeratunge, N., C. Béné, R. Siriwardane, A. Charles, D. Johnson, E. H. Allison, P. K. Nayak, and M.-C. Badjeck. 2014. Small-scale fisheries through the wellbeing lens. Fish and Fisheries 15 (2):255-279. http://dx.doi.org/10.1111/faf.12016

Weible, C. M. 2008. Caught in a maelstrom: implementing California marine protected areas. Coastal Management 36:350-373. http://dx.doi.org/10.1080/08920750802266387

Weigel, J.-Y., K. O. Mannle, N. J. Bennett, E. Carter, L. Westlund, V. Burgener, Z. Hoffman, A. S. Da Silva, E. A. Kane, J. Sanders, C. Piante, S. Wagiman, and A. Hellman. 2014. Marine protected areas and fisheries: bridging the divide. Aquatic Conservation: Marine and Freshwater Ecosystems 24(S2):199-215. http://dx.doi. org/10.1002/aqc. 2514

White, S. C. 2009. Bringing wellbeing into development practice. WeD Working Paper 09/50. Wellbeing in Developing Countries (WeD) ESRC Research Group, University of Bath, Bath, UK.

Wiber, M. G., S. Young, and L. Wilson. 2012. Impact of aquaculture on commercial fisheries: fishermen's local ecological knowledge. Human Ecology 40(1):29-40. http://dx.doi.org/10.1007/ $\underline{\text { s10745-011-9450-7 }}$

Wiek, A., and D. Iwaniec. 2014. Quality criteria for visions and visioning in sustainability science. Sustainability Science 9 (4):497-512. http://dx.doi.org/10.1007/s11625-013-0208-6

Woodcock, P., B. C. O’Leary, M. J. Kaiser, and A. S. Pullin. 2017. Your evidence or mine? Systematic evaluation of reviews of marine protected area effectiveness. Fish and Fisheries 18 (4):668-681. http://dx.doi.org/10.1111/faf.12196

Woodhouse, E., K. M. Homewood, E. Beauchamp, T. Clements, T. J. McCabe, D. Wilkie, and E. J. Milner-Gulland. 2015. Guiding principles for evaluating the impacts of conservation interventions on human well-being. Philosophical Transactions of the Royal Society B: Biological Sciences 370(1681):20150103. http://dx.doi.org/10.1098/rstb.2015.0103

Xu, L., D. Marinova, and X. Guo. 2015. Resilience thinking: a renewed system approach for sustainability science. Sustainability Science 10(1):123-138. http://dx.doi.org/10.1007/s11625-014-0274-4

Yin, R. K. 2014. Case study research: design and methods. Fifth edition. Sage, Thousand Oaks, California, USA. 